\title{
KONDISI OPTIMUM EKSTRAKSI THE SECANG
}

\author{
Oleh : \\ Ageng Priatni ${ }^{17}$ \\ Tatik Purwanti ${ }^{2}$
}

\begin{abstract}
Recently, Secang had productive be a kind of tea and sold broadly. In Dr. Ratu Safitri research had been known that Secang had antioxidant activity and power as radical scavenging but they were labile if extracted in water.

The purpose of this research is to know effect of temperature and time of Secang tea extraction and optimum conditions. In this research, secang tea was extracted in water. The temperature of extraction was varied of $50^{\circ} \mathrm{C}, 75^{\circ} \mathrm{C}$ $\& 100^{\circ} \mathrm{C}$ and time of extraction was varied of $1,3 \& 5$ minutes. Then extract was analyzed with Radical Scavenging DPPH (1,1-diphenyl-2-picrylhydrazyl) method.

The result of this research showed that increase of temperature and time of secang tea extraction caused yield of extract increasingly. Time caused increasing absorbance of extraction but tenperature was opposite. The optimum cinditions of secang tea extraction is $50^{\circ} \mathrm{C}$ and 5 minutes.
\end{abstract}

Key words : Secang tea, extraction, antioxidant

\section{PENDAHULUAN}

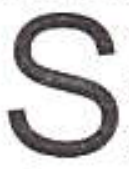

ecang atau sepang (Caesalpinia sappan L) merupakan tanaman hutan yang sering digunakan masyarakat sebagai obat tradisional untuk penyakit TBC, diare, disentri, penawar racun, sipilis, pengobatan sesudah melahirkan, katarak, mag dan rematik. Secang merupakan jenis tanaman yang termasuk Famili Leguminosae. Tanaman ini berupa perdu atau pohon kecil, tinggi 5 - $10 \mathrm{~m}$, berakar serabut, berduri banyak, daunnya majemuk, bersirip ganda (Heyne. K). Berdasarkan penelitian SAFITRI, R (2000) diketahui bahwa bagian kayu secang memiliki daya peredaman radikal bebas superoksida dan aktivitas antioksidan sebesar $100 \%$. Studi juga mengungkapkan ada lima senyawa aktif yaitu saponin, fitosterol, brazilin, tanin, flavonoid (Haryono, J) dan diantaranya tidak hanya mampu meredam radikal superoksida, tetapi juga memberikan efek peredaman yang sangat berarti terhadap radikal hidroksil yang lebih reaktif dan berbahaya. Zat antioksidan yang terdapat dalam tumbuhan ini bersifat labil terbukti bila serbuk kayu secang diseduh dengan air panas, hasil seduhannya lama kelamaan berubah warnanya menjadi semakin merah tua.

Kini secang sudah diolah menjadi produk minuman berupa teh dan banyak dijual luas sehingga masyarakat dapat dengan mudah mengkonsumsinya melalui cara diseduh atau dicelup dengan air. Akan tetapi, mengingat labilnya zat antioksidan yang ada pada teh secang tersebut menimbulkan pertanyaan, pada kondisi bagaimanakah masyarakat sebaiknya mengkonsumsi sehingga manfaat dari teh tersebut benar-benar dapat dirasakan.

Berdasarkan pertanyaan tersebut maka penelitian ini dilakukan dengan tujuan mengetahui pengaruh suhu dan waktu ekstraksi teh secang sehingga didapat kondisi optimum dari ekstraksi.

\footnotetext{
1.) Penelit Baristand industri Samarinơa
} 


\section{BAHAN DAN METODA}

Tahap awal dari penelitian ini adalah membuat sample atau contoh dengan cara simplisia kayu secang dipotong-potong dan dihaluskan/diblender hingga menjadi serbuk. Serbuk secang selanjutnya dioven hingga kadar air 10-15\% dan ditimbang seberat 2 gram untuk kemudian dikemas dengan filter paper.

Tahap kedua adalah ekstraksi. Contoh uji diekstraksi dengan pelarut air sebanyak $150 \mathrm{ml}$ pada suhu masing-masing $50^{\circ} \mathrm{C}, 75^{\circ} \mathrm{C} \& 100^{\circ} \mathrm{C}$ dengan variasi waktu ekstraksi $1,3 \& 5$ menit. Masing-masing contoh tersebut kemudian diuji aktifitas antioksidannya dengan metode Radical Scavenging pada DPPH (1,1-diphenyl-2-picrylhydrazyl). Dasar pengujian ini adalah penurunan konsentrasi dari larutan standar DPPH karena ternetralisir oleh antioksidan yang ada pada ekstrak yang ditandai dengan penurunan intensitas warna. Pengukuran intensitas warna larutan DPPH dilakukan dengan pembacaan absorbanns pada spektrofotometer pada ë514 nm. Dari besarnya absorban yang diperoleh dihitung besarnya aktifitas antioksidan dengan rumus $\frac{\mathrm{AC}-\mathrm{A}}{\mathrm{AC}} \times 100 \%$ dimana Ac: absorban standar 0,206 dan A: absorban ekstrak.

\section{HASIL DAN PEMBAHASAN \\ Rendemen Ekstrak}

Dari hasil ekstraksi dengan berbagai perlakuan di atas diperoleh berat ekstrak yang kemudian dikonversikan menjadi rendemen dimana hasilnya dapat dilihat pada Grafik 1.

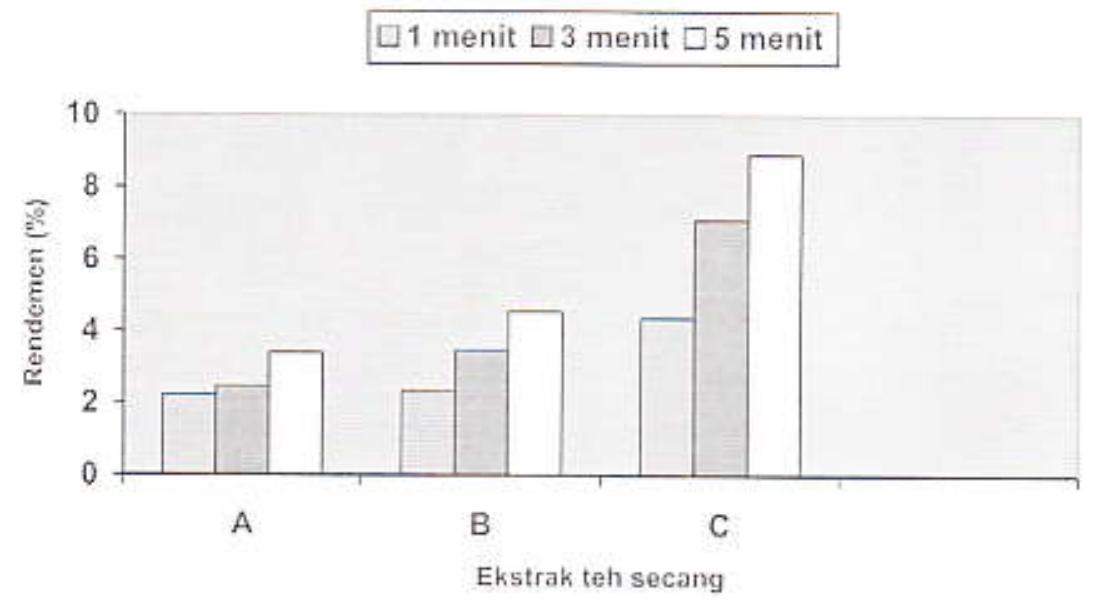

Keterangan:
A. Ekstrak teh secang pada perlakuan suhu $50^{\circ} \mathrm{C}$
B. Ekstrak teh secang pada perlakuan suhu $75^{\circ} \mathrm{C}$
C. Ekstrak teh secang pada perlakuan suhu $100^{\circ} \mathrm{C}$

Dari Grafik 1 dapat dilihat bahwa pada suhu ekstraksi $50^{\circ} \mathrm{C}, 75^{\circ} \mathrm{C} \& 100^{\circ} \mathrm{C}$, semakin lama waktu ekstraksi maka besarnya rendemen semakin bertambah. Begitu juga untuk waktu ekstraksi $1,3 \& 5$ menit, semakin meningkatnya suhu maka besarnya rendemen semakin bertambah. Hal ini disebabkan semakin banyaknya jumlah senyawa-senyawa yang terlarut seiring dengan meningkatnya suhu dan waktu ekstraksi.

\section{Absorban}

Pengaruh suhu dan waktu ekstraksi terhadap naik turunnya absorban ekstrak dapat dilihat pada Grafik $2 \& 3$. 
$\square 1$ menit $\square 3$ menit $\square 5$ menit

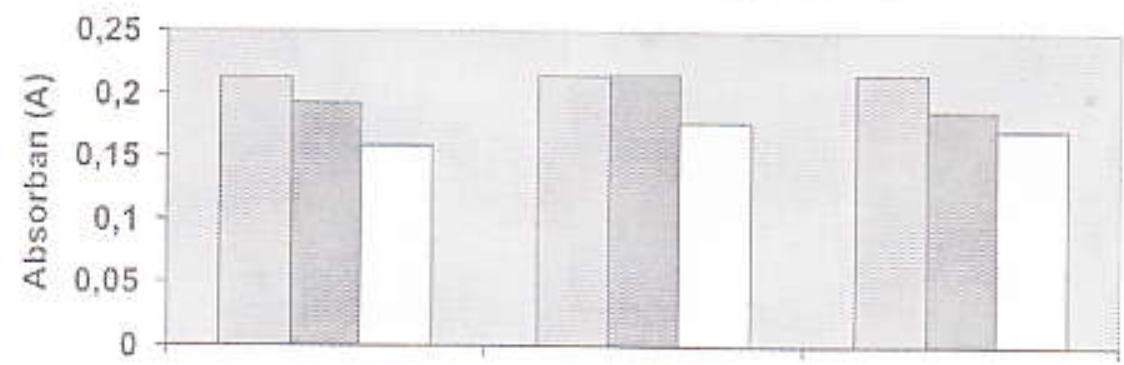

A

B

C

Esktrak teh secang

Grafik 2. Besarnya absorban ekstrak the secang pada berbagai perlakuan Keterangan:

A. Ekstrak teh secang pada perlakuan suhu $50^{\circ} \mathrm{C}$

B. Ekstrak teh secang pada perlakuan suhu $75^{\circ} \mathrm{C}$

C. Ekstrak teh secang pada perlakuan suhu $100^{\circ} \mathrm{C}$

Dari gambar 2 dapat dilihat bahwa pada suhu ekstraksi $50^{\circ} \mathrm{C}, 75^{\circ} \mathrm{C} \& 100^{\circ} \mathrm{C}$ semakin lama waktu ekstraksi maka absorbans ekstrak semakin menurun. Ini disebabkan karena terjadinya penurunan konsentrasi larutan DPPH akibat ternetralisirnya radikal-radikal bebas oleh zat antioksidan yang ada pada ekstrak. Ini menunjukkan untuk menangkap radikal bebas semakin baik.

$\square 500 \mathrm{C} \square 750 \mathrm{C} \square 1000 \mathrm{C}$

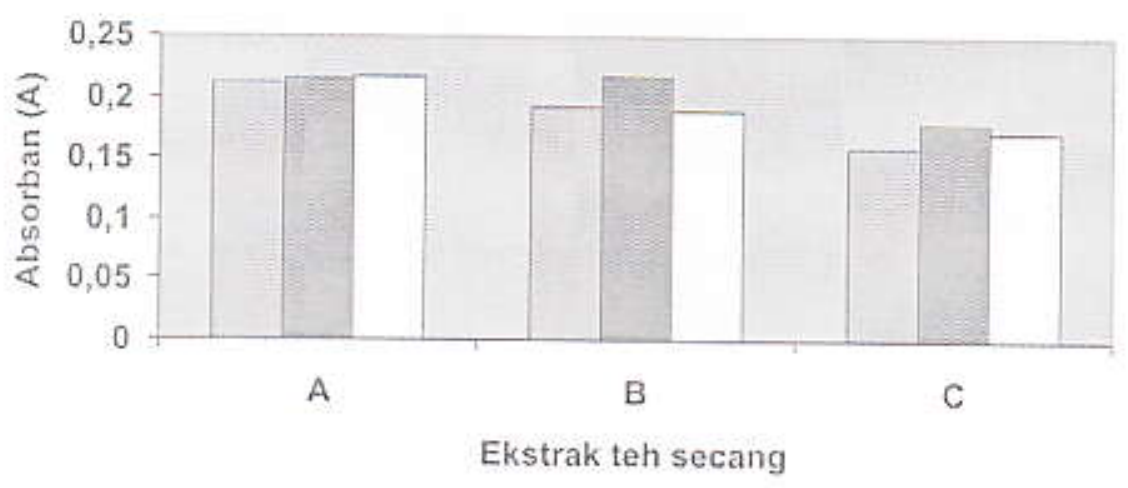

Grafik 3. Besarnya absorban ekstrak pada berbagai perlakuan

Keterangan :

A. Ekstrak teh secang pada perlakuan waktu 1 menit

B. Ekstrak teh secang pada perlakuan waktu 3 menit

C. Ekstrak teh secang pada perlakuan waktu 5 menit

Dari Grafik 3 dapat dilihat bahwa pada waktu ekstraksi 1 menit, kenaikan suhu mengakibatkan semakin besarnya absorban. Pada waktu ekstraksi 3 dan 5 menit terjadi kenaikan absorban pada suhu $75^{\circ} \mathrm{C}$ hal ini disebabkan karena kenaikan suhu menyebabkan terjadinya oksidasi pada ekstrak sehingga kemampuan untuk menangkap radikal bebas semakin menurun, akan tetapi pada suhu $100^{\circ} \mathrm{C}$ terjadi penurunan absorban kembali, hal ini disebabkan karena pada suhu tersebut zat aktif yang terlarut semakin besar (bisa dilihat dari Grafik 1) sehingga meningkatkan kemampuan zat antioksidan yang ada pada ekstrak. Namun penurunan absorban yang terjadi tidak terlalu besar. 


\section{Aktifitas Antioksidan}

Besarnya aktifitas antioksidan dapat dilihat pada tabel berikut ini. Standar yang digunakan adalah vitamin $C$ dengan absorban 0,206.

Tabel 1. aktifitas antioksidan ekstrak

\begin{tabular}{|c|c|c|c|}
\hline \multirow[b]{2}{*}{ No. } & \multicolumn{2}{|c|}{ Perlakuan } & \multirow[b]{2}{*}{$\begin{array}{c}{ }^{*} \text { Aktifasi } \\
\text { Antioksidan }(\%)\end{array}$} \\
\hline & $\begin{array}{l}\text { Suhu } \\
\left({ }^{\circ} \mathrm{C}\right)\end{array}$ & $\begin{array}{c}\text { Waktu } \\
\text { Ekstraksi } \\
\text { (Menit) }\end{array}$ & \\
\hline $\begin{array}{l}1 \\
2 \\
3\end{array}$ & $\begin{array}{l}50 \\
50 \\
50\end{array}$ & $\begin{array}{l}1 \\
3 \\
5\end{array}$ & $\begin{array}{r}-29,1 \\
6,31 \\
22,82\end{array}$ \\
\hline $\begin{array}{l}4 \\
5 \\
6 \\
7\end{array}$ & $\begin{array}{r}75 \\
75 \\
75 \\
100\end{array}$ & $\begin{array}{l}1 \\
3 \\
5 \\
1\end{array}$ & $\begin{array}{l}-4,37 \\
-4,37 \\
13,59 \\
-4,85\end{array}$ \\
\hline 8 & 100 & 3 & 8,74 \\
\hline 9 & 100 & 5 & 16,50 \\
\hline
\end{tabular}

Tabel 1 menunjukkan bahwa pada perlakuan 1, 4, 5 \& 7 aktifitas antioksidan bernilai negatif yang berarti kondisi yang diberikan pada perlakuan tersebut bukan kondisi yang baik untuk ekstraksi. Ini disebabkan karena pada kondisi-kondisi tersebut ekstrak menunjukkan sifat pro oksidan. Sementara untuk perlakuan 2, 3, 6, 8 \& 9 aktifitan antioksidan berbilangan positif yang berarti kondisi-kondisi tersebut baik digunakan untuk mengekstraksi contoh uji, namun bukan kondisi terbaik (optimal). Kondisi yang optimal terdapat pada perlakuan 3 yaitu pada suhu $50^{\circ} \mathrm{C}$ dan waktu ekstraksi 5 menit dengan aktifitas antioksidan sebesar 22,82 \% dimana kemampuan ekstrak untuk menetralisir radikal bebas merupakan yang terbesar dari semua perlakuan.

\section{KESIMPULAN DAN SARAN}

Semakin besar suhu dan waktu ekstraksi maka rendemen ekstrak juga semakin meningkat. Kenaikan ekstraksi menyebabkan kemampuan ekstrak untuk menangkap aktifitas antioksidan semakin tinggi sementara kenaikan suhu ekstraksi menyebabkan penurunan kemampuan. Dari penelitian ini juga diperoleh kondisi optimal dari ekstraksi teh secang dengan pelarut air yaitu pada suhu $50^{\circ} \mathrm{C}$ dan waktu ekstraksi 5 menit.

Dalam mengektraksi teh secang hendaklah dilakukan pada kondisi yang tepat agar manfaat yang diinginkan benar-benar dapat dirasakan. 


\section{UCAPAN TERIMA KASIH}

Ucapan terima kasih diberikan kepada Baristand Industri Samarinda sebagai penyandang dana dan Kepala Baristand Industri Samarinda atas kesediannya dalam memberikan tempat, alat dan bahan.

\section{DAFTAR PUSTAKA}

Safitri, R., 2000. Ekstraksi dan Identifikasi Antioksidan dari Tumbuhan Jamu Kayu Secang (Caesalpinia Sppan Linn), (laporan Penelitian) Fakultas MIPA Universita Padjajaran, Bandung.

Harjono, J.,1985. Tanaman obat Indonesia, hal.23, Ditjen Pengawasan Obat \& Makanan , Departemen Kesehatan RI, Jakarta.

Heyne, K., 1987. Tumbuhan Berguna Indonesia Il, hal .534, Badan Litbang Kehutanan, Jakarta. 